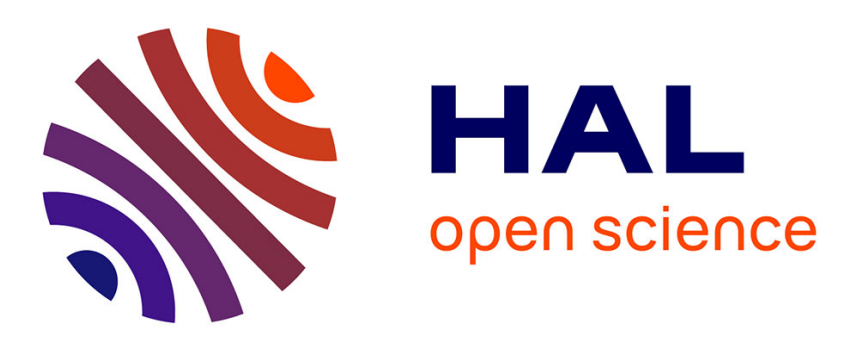

\title{
Biotic and abiotic determinants of the formation of ant mosaics in primary Neotropical rainforests
}

Alain Dejean, Arthur Compin, Jacques H.C. Delabie, Frédéric Azemar, Bruno Corbara, Maurice Leponce

\section{- To cite this version:}

Alain Dejean, Arthur Compin, Jacques H.C. Delabie, Frédéric Azemar, Bruno Corbara, et al.. Biotic and abiotic determinants of the formation of ant mosaics in primary Neotropical rainforests. Ecological Entomology, 2019, 44 (4), pp.560-570. 10.1111/een.12735 . hal-02338140

\author{
HAL Id: hal-02338140 \\ https://hal.science/hal-02338140
}

Submitted on 19 Nov 2020

HAL is a multi-disciplinary open access archive for the deposit and dissemination of scientific research documents, whether they are published or not. The documents may come from teaching and research institutions in France or abroad, or from public or private research centers.
L'archive ouverte pluridisciplinaire HAL, est destinée au dépôt et à la diffusion de documents scientifiques de niveau recherche, publiés ou non, émanant des établissements d'enseignement et de recherche français ou étrangers, des laboratoires publics ou privés. 


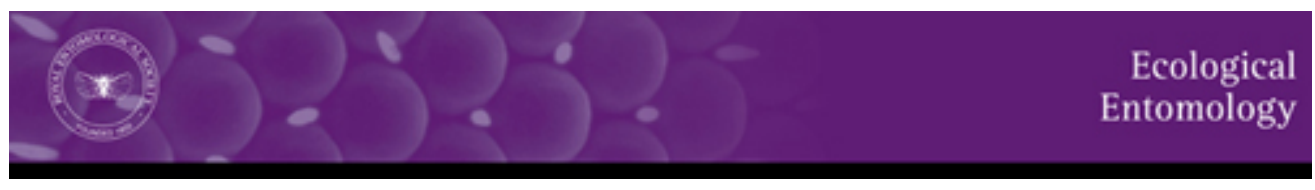

\section{Biotic and abiotic determinants of the formation of ant mosaics in primary Neotropical rainforests}

\begin{tabular}{|r|l|}
\hline Journal: & Ecological Entomology \\
\hline Manuscript ID & Draft \\
\hline Manuscript Type: & Original Article \\
\hline Author: & n/a \\
\hline Complete List of Authors: & $\begin{array}{l}\text { Dejean, Alain; CNRS-Guyane, } \\
\text { Compin, Arthur; Universite Toulouse III Paul Sabatier, FSI } \\
\text { Azémar, Frédéric; Universite Toulouse III Paul Sabatier, FSI } \\
\text { Delabie, Jacques Hubert Charles; Cocoa Research Center, SEFIT; } \\
\text { Universidade Estadual de Santa Cruz, Departamento de Ciências Agrárias } \\
\text { e Ambientais } \\
\text { Corbara, Bruno; Université Clermont Auvergne, CNRS, LMGE, F-63000 } \\
\text { Clermont-Ferrand, France } \\
\text { Leponce, Maurice; Royal Belgian Institute of Natural Sciences (RBINS), } \\
\text { Rue Vautier 29, B-1000 Brussels (Belgium) }\end{array}$ \\
\hline Keywords: & $\begin{array}{l}\text { ant mosaics, connections on the ground, host tree attractiveness, } \\
\text { indicators of disturbance, primary Neotropical rainforest, territoriality }\end{array}$ \\
\hline
\end{tabular}

\section{SCHOLARONE


1 Biotic and abiotic determinants of the formation of ant mosaics in primary Neotropical

2 rainforests

3

4 Alain Dejean ${ }^{1,2}$, Arthur Compin ${ }^{1}$, Jacques H. C. Delabie ${ }^{3}$, Frédéric Azémar ${ }^{1}$, Bruno

5 Corbara ${ }^{4}$ and Maurice Leponce ${ }^{5,6}$

6

$7 \quad{ }^{1}$ Ecolab, Université de Toulouse, CNRS, Toulouse, France, ${ }^{2}$ CNRS, UMR EcoFoG, AgroParisTech, 8 Cirad, INRA Orcid ID: https://orcid.org/0000-0002-3561-2248, Université des Antilles, Université de

9 Guyane, 97310 Kourou, France, ${ }^{3}$ U.P.A. Laboratório de Mirmecologia, Convênio UESC/CEPLAC,

10 C.P. 7, 45600-000 Itabuna, Bahia, Brazil, ${ }^{4}$ Université Clermont Auvergne, CNRS, LMGE, F-63000

11 Clermont-Ferrand, France, ${ }^{5}$ Biodiversity Monitoring \& Assessment, Royal Belgian Institute of

12 Natural Sciences (RBINS), Rue Vautier 29, B-1000 Brussels, Belgium, ${ }^{6}$ Behavioural \& Evolutionary

13 Ecology, Université Libre de Bruxelles (ULB), Av. F.D. Roosevelt 50, B-1050 Brussels, Belgium

14

15 Running title: A Neotropical ant mosaic

16

17 Correspondence: Alain Dejean, Ecolab, Université Toulouse 3, 118 route de Narbonne 31062,

18 Toulouse cedex 9, France. E-mail: alain.dejean@wanadoo.fr. Tel.: (33) 561558931

19 
20 Abstract. 1. Ants are widespread in tropical rainforests, including in the canopy where

21 territorially dominant arboreal species represent the main part of the arthropod biomass.

2. The mapping of the territories of dominant arboreal ant species, the use of a null model analysis and a pairwise approach permitted us to show the presence of an ant mosaic on the upper canopy of a primary Neotropical rainforest $(\approx 1$ ha sampled; 157 tall trees from 28 families). Although Neotropical rainforest canopies are frequently irregular with tree crowns at different heights breaking the continuity of the territories of dominant ants, the latter are preserved via trails laid on the ground or underground galleries.

3. The distribution of the trees influences the structure of the ant mosaic, something related to the attractiveness of tree taxa for certain arboreal ant species rather than others.

4. Small-scale natural disturbances, most likely strong winds in the area studied (presence

31 of canopy gaps) play a role by favoring the presence of two ant species typical of secondary formations: Camponotus femoratus and Crematogaster levior, which live in parabiosis (i.e., share territories and nests but lodge in different cavities) and build conspicuous ant gardens. Also, pioneer Cecropia myrmecophytic trees were noted.

Key words. ant mosaics, connections on the ground, host tree attractiveness, indicators of 


\section{Introduction}

Ants dominate the fauna of tropical rainforest canopies both in terms of biomass and number of individuals, an ecological success possible thanks to their entirely or partially herbivorous diet as they feed on extrafloral nectar, food bodies and hemipteran honeydew (Blüthgen et al., 2004; Davidson et al., 2003). Yet, only a limited number of ant species with large colonies are concerned, something corresponding to the notion of 'numerical dominance' (the predominance of a species in frequency of occurrence in the ant community). When combined with 'behavioral dominance' (dominance in interspecific competition due to superior fighting and/or recruitment abilities) this results in 'ecological dominance' (see Davidson, 1998).

Certain canopy ants correspond rather to the latter case as they are characterized by very populous colonies of up to several million workers, large and/or polydomous nests (see Fig. 1), and an absolute intra- and interspecific territoriality so that they are called 'territorially dominant arboreal ant species' (TDAAs) (Majer, 1993).

Two TDAAs can share the same territory (i.e., 'co-dominance') when they have complementary rhythms of activity (i.e., one is diurnal, the other is nocturnal), when their workers avoid each other with only occasional conflicts for food, or during "parabiosis" (i.e., two species share the same territories and nests, but lodge in different cavities of these nests) (Majer, 1993; Dejean et al., 2007, 2012; Vicente \& Izzo, 2017; Yusha et al., 2017).

TDAAs tolerate within their territories the presence of 'non-dominant' species with small colonies that represent only $\approx 5 \%$ of the ant biomass and individuals, but are species-rich (e.g., 43 species on one tree; 85 species on two trees) (Hölldobler \& Wilson, 1994; Tobin, 1997). Exceptionally, colonies of non-dominant ants can become large enough to occupy and defend the crown of a tree; they are then called 'subdominants' (Majer, 1993; Majer et al., 1994). 
When the tree crowns are contiguous or interconnected by liana, the TDAAs' territories are distributed in a mosaic pattern creating what has become known as 'arboreal ant mosaics' (Majer, 1972, 1993). Ant mosaics have been noted in the upper canopies of tropical African, Asian, Bornean, New Guinean and Neotropical rainforests and tree crop plantations (Majer, 1993; Adams, 1994; Armbrecht et al., 2001; Blüthgen \& Stork, 2007; Davidson et al., 2007; Dejean et al., 2007, 2010, 2015, 2018; Pfeiffer, 2008; Fayle et al., 2013; Ribeiro et al., 2013; Klimes, 2017; Yusah et al., 2018; Leponce et al., 2019). Nevertheless, ant mosaics are often absent from the 'sub-canopy' likely due to the scarcity of hemipterans whose honeydew is necessary to fuel the TDAA colonies (Floren \& Linsenmair, 2000; Blüthgen \& Stork, 2007; Dejean et al., 2007, 2018; Ribeiro et al., 2013). Yet, very large TDAAs colonies can occupy vast spaces involving all canopy growth stages (Dejean et al., 2007; Klimes et al., 2015).

Founding queens do not install their colony by chance in tree crowns as selective plant attractiveness has been shown experimentally for both plant-ants and TDAAs (Djiéto-Lordon \& Dejean, 1999a,b). Although tempered by the extension of the territories over adjacent trees (of different species) with the increasing size of the TDAAs' colonies, this effect remains perceptible (Dejean et al., 2007, 2015, 2018; Fayle et al., 2015). Also, an ontogenetic succession of ant species follows the sequence of stages in tree and vegetal formation development (Watt et al., 2002; Kenne et al., 2003; da Conceição et al., 2015; Dejean et al., 2016). Finally, the forest structure plays a role in the formation of ant mosaics. For example, tropical African rainforests have proportionately more 'large' trees (i.e., tall with a wide trunk and a large crown) than do the tropical forests of other continents, likely due to fewer disturbances over recent decades (Lewis et al., 2013; see projections of African trees in Fig. 2). This explains why the Neotropical rainforest canopies are frequently irregular with tree crowns at different heights likely resulting from treefall gaps, breaking the continuity of the territories of the TDAAs (Ribeiro et al., 2013). 
Studying ant mosaics is important because TDAAs prevent attended hemipterans from proliferating (Styrsky \& Eubanks, 2007) and protect their host trees from defoliating insects through their predatory behavior or by deterring them either actively or simply through the presence of their long-lasting landmarks (Majer, 1993; Dyer, 2002; Floren et al., 2002;

Dejean et al., 2007; Offenberg et al., 2007).

Ant mosaics can be impacted by canopy gaps created by the death of a tree or the fall of trees by snapping or uprooting due to strong winds that are considered small-scale natural disturbances. An indirect impact also occurs during the formation of large gaps as they permit light-demanding tree species with low wood density (e.g., pioneer trees) to develop quickly from seeds (Schnitzer et al., 2008).

In this study, conducted in a primary moist Neotropical rainforest situated in French Guiana, we aimed to determine: (1) if an ant mosaic exists in the upper canopy, (2) if TDAA workers follow trails on the ground that interconnect neighboring trees to compensate the irregularity of the canopy or if they use underground galleries, (3) if the host tree taxa influence the TDAAs' distribution and (4) if locally strong winds due to the neighboring presence of an inselberg affect the distribution of the TDAAs, favoring certain of them.

\section{Materials and methods}

\section{Study site, tree mapping and identification}

The Nouragues Ecological Research Station $\left(4^{\circ} 05^{\prime} \mathrm{N}-52^{\circ} 41^{\prime} \mathrm{W}\right)$, dominated by a partly denuded Inselberg (430 asl), is located within the Montagnes Balenfois massif typical of the Guiana Shield. The radiocarbon dating of charcoal and pollen coring suggest that the forest cover has remained intact over at least 3000 years, but with fires occurring $\approx 500$ years ago. A variety of vegetal formations occur within a radius of $1.5 \mathrm{~km}$, including: (1) the inselberg's 
113 summit, (2) a low transition forest, (3) a wide, forested plateau, and (4) a liana forest whose

114 origin might be due to strong winds or a microtornado. The climate is moist tropical, with a

115 mean annual rainfall of $3000 \mathrm{~mm}$ distributed over $\approx 280$ days; the daily mean temperature

116 ranges from $20.3^{\circ} \mathrm{C}$ to $33.5^{\circ} \mathrm{C}$ (Grimaldi \& Riera, 2001; Tymen et al., 2016).

117 In the Nouragues area, strong winds, likely due to the vicinity of the Inselberg, generated

118 on the plateau the formation of a liana forest and large gaps. Liana forests, caused by

119 windthrow events resulting in $>1$ ha gaps, generally persist for a long time, blocking the forest

120 succession (van der Meer \& Bonger, 1996; Stefan et al., 2010; Tymen et al., 2016).

121 Field studies were conducted on the plateau (2006-2010) where the staff of the Nouragues

122 Ecological Research Station has established grid trails every $100 \mathrm{~m}$, creating 1 ha forest plots

123 over $70 \mathrm{ha}$; the trees have been mapped, measured, tagged and identified (Poncy et al., 2001).

Canopy access, gathering TDAA samples and mapping the ant mosaic

126 We used the single rope technique to reach the upper canopy tree crowns, permitting us to

127 gather samples from 157 trees. To collect ant samples, we cut off two to four branches (10-15

$128 \mathrm{~cm}$ in diameter) from each tree. Because arboreal ants mark these branches as part of their

129 territories (i.e., the workers deposit "landmarks" that can last for more than 1 year; Beugnon

130 \& Dejean, 1992; Offenberg, 2007), several dozen to thousands of workers remained on them

131 for more than 1 hour after the sectioning of the branches (Dejean et al., 2007, 2010, 2015).

132 Using entomological aspirators, we were thus able to collect samples of the ants crawling on

133 the fallen branches or hidden in hollow twigs.

134 In contrast to trapping methods permitting large numbers of species to be collected, this

135 branch clipping method allows us to sample numerically dominant ants and obtain

136 information on the co-occurrence of these species on the same branches, and so interspecific 
137 tolerance. Thus, branch clipping does not permit to obtain a representative picture of 'non-

138 dominant' ant species (not considered here), something needed in diversity studies.

139 We also verified at the bases of trees if there were nests of Ectatomma tuberculatum or

140 Paraponera clavata, two ground-nesting, arboreal foraging species known as dominant or co-

141 dominant (see studied ant nesting habits in Table 1).

142 The presence of arboreal ant trails on the ground was noted during a sampling of litter-

143 dwelling ants in the area studied (Groc et al., 2014). We therefore verified if the trails

144 interconnected the bases of different trees and if certain workers transported brood and

145 nestmates from one tree to another (see Orivel \& Dejean, 2001). As most of the TDAAs in the

146 area are diurnal, each hour between 8:00 and 18:00 during five non-consecutive sunny days,

147 we walked along the same path that was chosen because it passed between trees whose

148 canopies were not in contact whereas they share the same TDAAs.

149 Because E. tuberculatum and Crematogaster stollii use underground galleries to connect

150 trees (Table 1) when one or the other species was noted on groups of trees we sought to

151 determine if these trees belonged to the same colony. We thus sprayed paint on workers from

152 one nest (from $\approx 60 \mathrm{~cm}$ so that each ant had only some spots) and verified during the three

153 next days if ants with spots of paint were present on the adjacent trees. For E. tuberculatum,

154 we unearthed a nest from the base of a tree and sprayed blue paint as the workers are

155 yellowish. For $C r$. stollii, we opened galleries at the base of a tree and sprayed yellow paint as

156 the workers are black; the verification required opening galleries of adjacent trees.

157 All these techniques permitted us to pinpoint the exact limits of the TDAAs' territories,

158 allowing the precise mapping of these territories (Fig. 2).

159 Ant samples were preserved in $70 \%$ ethanol for later identification; voucher specimens

160 were deposited in the Laboratório de Mirmecologia, UESC/CEPLAC, Ilhéus, Bahia, Brazil

161 and in the Royal Belgian Institute of Natural Sciences, Brussels, Belgium. 
Rarefaction curves of tree and ant assemblages

164 Diversity statistics were calculated using EstimateS 9.1 software (Colwell, 2013) with 100

165 randomizations of the sampling order without replacement. To estimate sampling

166 completeness, the Chao1 (tree data, abundance-based) and Chao2 (ant data, occurrence-based)

167 non-parametric estimators of total species richness were calculated (Colwell et al., 2004).

168 Because ant mosaics correspond to non-random patterns of co-occurrence related to the 169 mutual exclusion of TDAAs, we used a fixed-equiprobable null model and the C-score co170 occurrence index with the sequential swap algorithm and 5, 000 iterations available in the 171 EcoSim software (Gotelli \& Entsminger, 2004; Blüthgen \& Stork, 2007; Fayle et al. 2013).

172 The fixed-equiprobable algorithm maintains the species occurrence frequencies and considers

173 all sites (trees) equiprobable (Gotelli, 2000). The C-score index used in combination with the

174 fixed-equiprobable algorithm generally has good statistical properties and is not prone to false 175 positives (Gotelli, 2000). Specific associations between the most frequent ant species (i.e., 176 present on more than $10 \%$ of the 157 trees sampled) were tested using Chi-square tests with

177 Yates' correction. When field observations revealed that a single tree crown belonged to two

178 different territories ( $\mathrm{n}=7$ cases), the species involved were encoded separately in the co-

179 occurrences matrix (the whole results in a matrix of 6 ant species $x 164$ sampling units).

181 Testing the relationships between tree family (or subfamily) and ant species

182 To determine the influence of host trees in shaping the ant mosaic, the TDAAs recorded

183 for each tree family (or subfamily for the Fabaceae) allowed us to build a ' 10 ant species x 31

184 tree families' matrix. TDAAs found only occasionally were eliminated to avoid the effect of

185 outliers as were the 11 cases for which the trees were not identified, so that this study was

186 conducted on 144 out of the 157 trees sampled. 
To ordinate the host tree families based on the TDAAs they sheltered, we conducted a nonmetric multidimensional scaling (NMDS) on a matrix of dissimilarity based on the BrayCurtis dissimilarity index using 100 random starts. The final stress value of $0.06<0.1$ can be acknowledged as providing a good representation for a 2-D configuration. A hierarchical clustering using the 'complete' agglomeration method (NbClust package) on the dissimilarity matrix resulted in eight clusters of ant species; this was the best clustering scheme obtained using the 'majority rule' (24 indices computed). These analyses were conducted using the Vegan and NbClust packages in R software (R Development Core Team, 2015).

\section{Identifying different degrees of 'small-scale disturbance' between five Guianese rainforests}

Because the parabiotic, ant-garden ants Camponotus femoratus (Formicinae) and Crematogaster levior (Myrmicinae) are characteristic of pioneer formations (Dejean et al., 2000) but are also present in rainforest canopies, particularly around treefall gaps (Vicente \& Izzo, 2017), they can serve as a basis for comparison to establish different degrees of 'smallscale natural disturbances' between rainforests. This needs to be distinguished from major disturbances such as those caused by hurricanes or by humans.

Thus, we compared the number of trees sheltering these ant garden ants versus those sheltering the other dominant ants between five Guianese rainforests (data from the present study, Dejean et al. 2018, and Leponce et al. 2019). A set of Fisher's exact-tests was used for pairwise comparisons; simultaneous comparisons were adjusted using the false discovery rate, BH correction (Pike, 2011). We also compared the number of tree crowns sheltering these ant-garden ants between light-demanding and other types of trees on the Nouragues plateau as well as the frequency of light-demanding trees between the Nouragues plateau and Paracou, two terra firme rainforests (see data in Appendix S1A, B). 
Results

General points

The 157 trees sampled represented 77 species belonging to 29 families, the Lecythidaceae (30 trees) being the most frequent followed by the Fabaceae (28 trees) (Appendix S1), but we noted the incompleteness of the tree survey (Fig. 3a). The projected on-ground crown map (Fig. 2) corresponds to the location of individual trees in more or less circular horizontal projected crown areas whose diameters varied from 5-6 $\mathrm{m}$ to, exceptionally, 14-15 m (see tree \#11M11); one can note the presence of numerous gaps between these tall canopy trees. A representative part of the dominant ant assemblage was inventoried (Fig. 3b). Among the 16 ant species recorded (nine genera from six subfamilies), only Camponotus rapax is a non-dominant species, here in the situation of sub-dominant on one tree: \#11L447. The most frequent species, Cr. levior, noted on $43.95 \%$ of the tree crowns, generally nests in parabiosis with Ca.femoratus, both sharing ant gardens (Table 1; Figs. 1, 2; Appendix S1).

\section{Mapping the territorially dominant ant territories}

Despite the absence of direct contact between certain tree crowns or their connection via lianas in many cases, the cohesion of these territories is possible thanks to the presence of trails on the ground that interconnect the trees. These trails are used during the warmest hours of the day (11:00-15:00), the workers walking in both directions transporting larvae, nymphs 232 and nestmates. This was noted for Az. jelskii (connections between trees \#11L403, \#11L399 233 and \#11L402), Az. instabilis (trees \#11M77 and \#11M66), Ca.femoratus and Cr. levior 234 (group of trees whose limits are \#11M53,\#11M37,\#11M93 and \#11M90; trees \#11M111 and \#11M128; Fig. 2). The nests of Dolichoderus bidens are interconnected by constantly-used 
237

Cr. stollii workers confirmed that via underground galleries neighboring trees sheltering these ant species belonged to the territory of one colony (e.g., for Cr. stollii see groups \#11M104, \#11M135 and \#11N136; \#11L556,\#11L458 and \#11M106; Fig. 2).

We also noted tree crowns divided into separate territories (e.g., \#11L408, \#11L411, \#11L522, \#11L403, \#11M126, \#11M128, \#11M111; Fig. 2).

In addition to the cases of parabiosis between $\mathrm{Ca}$. femoratus and $\mathrm{Cr}$. levior noted on 56 tree crowns, co-dominance was frequent when involving $C r$. stollii which was often associated with E. tuberculatum (i.e., on 16 trees out of 28 sheltering Cr. stollii; Table 2; Fig. 2; Appendix S1). Other cases of co-dominance concerned Cr. levior and Cephalotes atratus (tree \#11L495), Azteca instabilis and Az. jelskii (trees \#11L411 and \#11M79), and Az. instabilis and Daceton armigerum (tree \#11M128) or Dolichoderus bispinosus (tree \#11L408) (Fig. 2; Appendix S1).

The null model analysis confirmed the existence of a mosaic by revealing less species cooccurrence than expected by chance between the six most common ant species, indicating a competitively structured assemblage (observed C-score $=912.9$; simulated C-score $=614.6$; $\mathrm{P}<0.001)$. The pairwise approach showed that Crematogaster levior and Ca.femoratus were positively associated with each other but negatively associated with all four other frequent species, while Cr. stollii was positively associated with E. tuberculatum (Table 2).

\section{Influence of tree family (or subfamily) on the ant species distribution}

The NMDS ordination of Bray-Curtis distances and the complete agglomeration method showed a strong host tree selectivity by the 10 most frequent dominant ant species as eight clusters were delimited with, as expected, the two parabiotic, ant-garden ants, Cr. levior and Ca.femoratus, grouped together. Azteca jelskii was associated with D. bispinosus, whereas all other ant species were related to a specific set of tree taxa (Fig. 4). Thus, the sampling size 
262

was large enough to obtain evidence that the formation of ant mosaics depends to some extent on the host trees.

\section{Identifying different degrees of small-scale disturbances between five Guianese rainforests}

The rate of presence of the ant-garden ants Ca.femoratus and Cr. levior on the Nouragues plateau (present study) and the Mitaraka swamp forest was not significant, but significantly higher than the three other forests (Table 3). Among the latter, the difference between the forest of Paracou and the Mitaraka plateau was not significant, but was significant between them and the Petit Saut forest (ant-garden ants absent there) (Table 3).

The number of tree crowns sheltering Ca.femoratus and/or Cr. levior on the Nouragues plateau was not significant between light-demanding and other types of trees ( 8 cases out of $20 ; 40 \%$ versus 59 out of $120 ; 49.17 \%$; Fisher's exact-test: $\mathrm{P}=0.48)$. Also, the comparison between the Guianese terra firme rainforests of the Nouragues plateau and Paracou resulted in non-significant differences in the relative numbers of light-demanding tree species (26 out 146 trees identified versus 22 out of 109; Fisher's exact-test: $\mathrm{P}=0.87$ ) (see Appendix S1).

\section{Discussion}

\section{Ant mosaic characteristics and traits related to ant species dominance}

Although Neotropical rainforest canopies are reputed to be irregular, breaking the continuity of the territories of TDAAs (Ribeiro et al., 2013), we show the existence of an ant mosaic. This was demonstrated by mapping the spatial segregation of the numerically dominant ants in the upper canopy (Fig. 2), the use of a null model co-occurrence and a pairwise approach. 
All already known cases of arboreal ant dominance were recorded including classical

287 TDAAs, co-dominance and even a colony of the non-dominant species Ca. rapax in the 288 position of sub-dominance (small Ca. rapax colonies nest in old branches of trees; Table 1).

In addition to the parabiosis between $\mathrm{Cr}$. levior and $\mathrm{Ca}$. femoratus, most cases of co-

290 dominance involved Cr. stollii whose workers moreover defend territories vis-à-vis other

291 TDAAs even though they mostly move inside carton galleries (Longino, 2007; Schmidt \&

292 Dejean, 2018). They were frequently associated with E. tuberculatum (Table 2). Some other

293 cases of co-dominance correspond to tolerance between TDAA foraging workers (Fig. 2,

294 Appendix S1).

295 A representative part of these dominant arboreal ants was inventoried in the upper canopy

296 (Fig. 3), whereas this was not the case for trees for which a very large sampling effort might

297 be necessary due to the hyperdiverse Amazonian rainforests (see Poncy et al., 2001).

Importantly, although the TDAA territories frequently spread over several tree crowns,

some tree crowns were divided into two or more separate territories (Fig. 2; Ribeiro et al., 2013; Dejean et al., 2018). This situation needs to be handled with care to avoid confusing it

301 with cases of co-dominance causing wrong data to be used in the statistical analyses leading 302 to erroneous interpretations.

A complementary survey conducted at ground level is necessary because it will allow trees

304 whose crowns are not interconnected by contact or via lianas to be grouped in the same

305 territory and, here too, avoid misinterpretations. Indeed, we showed that the workers of five

306 TDAAs use trails on the ground or the low vegetation to interconnect trees whose crowns are

307 not in contact, permitting them to exchange brood and workers and thus to maintain the

308 colony odor as is known for two ground-nesting ant species (Beugnon et al., 2001; Orivel \&

309 Dejean, 2001). Furthermore, we confirmed that the colonies of Cr. stollii and E. tuberculatum

310 interconnect neighboring trees belonging to their territory via underground galleries. 
Forest canopy functioning and ant mosaics

313 Among the functional traits of ant species involved in ant mosaics (e.g., colony size,

314 territoriality, host-tree preference), the size of the colonies is primordial. For example,

315 Camarota et al. (2016) demonstrated that, in the Brazilian Cerrado (a savanna with trees $\approx 6 \mathrm{~m}$

316 in height), null model analyses conducted on all ant species noted on trees resulted in random

317 co-occurrence patterns. Yet, the same approach conducted on the most frequent species

318 resulted in a segregated pattern, something confirmed through a pairwise approach (a pairwise

319 approach also permitted Adams et al., 2017 to identify segregated TDAAs in a Panamanian

320 rainforest). Consequently, numerical dominance can be enough for null model analyses to

321 illustrate a segregated pattern of occurrence (see other details in Blüthgen \& Stork, 2007).

322 Indeed, if ant abundance in tropical rainforest canopies surpasses that of all other animal taxa,

323 this is due to dominant species because non-dominant ants, that are species-rich, represent

324 only $\approx 5 \%$ of the ant biomass and individuals (Hölldobler \& Wilson, 1994; Tobin, 1997).

Roles of host trees and small-scale disturbances on the distribution of dominant ants

Host tree specificity due to attractive chemicals acting on founding queens and workers, well known for myrmecophyte-ant relationships, was generalized to include TDAAs during ethological experiments showing the basis of nest-site selection by these arboreal ants (Djiéto330 Lordon \& Dejean, 1999a,b). This was also shown via the distribution of the dominant ants'

331 territories even though the latter expand as the colonies age (i.e., they occupy neighboring 332 trees whose taxa are distributed by chance) (Dejean et al., 2007, 2015; 2018; this study). Our 333 approach was valid as we indeed noted that the two ant-garden ants shared the same cluster 334 and that the plant-ant Az. ovaticeps was associated with its mutualist host mymecophyte, 335 Cecropia obtusa (Cecropiaceae) (Fig. 4). 
Another important characteristic is the dominance of the ant-garden ants Ca.femoratus and Cr. levior in the ant mosaic studied, two species typical of pioneer formations that are also

338 frequent around treefall gaps and in plantations (Dejean et al., 2000; Vicente \& Izzo, 2017).

339 Thus, their presence in primary rainforests (Dejean et al., 2018; Leponce et al., 2019; this

340 study) might indicate some degrees of past disturbances or of frequent disturbances. The

341 comparison between Guianese rainforests showed that the rate of presence of these two ant

342 species was significantly higher on the Nouragues plateau than in other terra firme Guianese

343 rainforests, but similar to that of a swamp forest (Table 3). Note that the characteristics of

344 Neotropical swamp forests are similar to that of young, secondary forests and treefall gaps in

345 old-growth forests (Souza \& Martins 2005).

346 Furthermore, the presence of the typical pioneer species Ce. obtusa shows that canopy

347 gaps existed in the past; later these trees reached the canopy and so were recorded in this

348 survey (Appendix S1; Fig. 2).

Relationships between small-scale natural disturbances and the presence of ant-garden ants

Because the comparison of the frequency of the ant-garden ants on the Nouragues plateau

352 and the comparison of the numbers of light-demanding tree species between the Nouragues

353 plateau and Paracou resulted in non-significant differences, we failed to show that these ants

354 select 'light-demanding tree taxa' rather than others. Thus, the neighboring presence of

355 canopy gaps seems enough to favor the presence of these ants in the situation studied (i.e.,

356 whether the host trees are light-demanding or not).

357 Therefore, the abiotic disturbances represented by frequent strong winds and the formation 358 of large canopy gaps are likely the main cause of the abundance of the ant-garden ants $\mathrm{Ca}$.

359 femoratus and Cr. levior that withstand these effects better than do competitive TDAAs (see 
Vicente \& Izzo, 2017). Because they build conspicuous ant gardens easy to locate (Fig. 1), they might serve as indicators of different degrees of small-scale natural disturbances.

In conclusion, ant mosaics exist in Neotropical rainforests despite the frequent small-scale natural disturbances and absence of contact between tree crowns due to the structure of the trees. This is due to the TDAAs' territoriality, host tree taxa selection, contact between tree crowns and interconnection via liana, plus the ability of certain TDAAs to interconnect trees belonging to their territories using trails on the ground or underground galleries, whereas an abiotic influence plays a role in the form of strong winds and the formation of large canopy gaps.

\section{Acknowledgements}

We would like to thank Jérôme Chave for furnishing us the maps of the area studied, the identification of the trees and information on tree functional traits, the staff of the Nouragues Ecological Research Station for logistical assistance, Lannick Rerat for sampling ants from the canopy using the singlerope technique, Eleonore Compin for technical help and Andrea Yockey for proofreading the manuscript. Financial support for this study was provided by the "Investissement d'Avenir" grants managed by the French Agence Nationale de la Recherche (CEBA, ref. ANR-10- LABX-25-01) and a research grant from the Brazilian Conselho Nacional de Desenvolvimento Cientifico e Tecnológico $(C N P q)$ for JHCD. AD, BC and ML designed the experiments; AD and ML conducted the field study; JHCD identified the ants; AC and ML analyzed the data; FA prepared the illustrations; AD wrote the paper, and all authors made significant contributions in terms of ideas and revisions. All authors have approved the manuscript and there are no conflicts of interest.

\section{Supporting Information}


387

Additional Supporting Information may be found in the online version of this article under the DOI reference: 10.1111/een.??????

Appendix S1. A. Identification of the 157 trees studied in the Nouragues Ecological Research Station and the dominant ant species they sheltered in their crowns (the codes are nailed to the trunks of the trees at $\approx 1.60 \mathrm{~m}$ in height). (LD): light-demanding tree species including pioneer tree species (26 species out of 120 taxa identified). B. For comparison, selection of light-demanding tree species in the forest of Paracou, French Guiana (see Dejean et al., 2018).

\section{References}

Adams, B.J, Schnitzer, S.A. \& Yanoviak, S.P. (2017) Trees as islands: canopy ant species richness increases with the size of liana-free trees in a Neotropical forest. Ecography, 39, 001-009.

Adams, E.S. (1994) Territory defense by the ant Azteca trigona: maintenance of an arboreal ant mosaic. Oecologia, 97, 202-208.

Armbrecht, I., Jiménez, E., Alvarez, G., Uloa-Chacon, P. \& Armbrecht, H. (2001) An ant mosaic in the Colombian rain forest of Chocó (Hymenoptera: Formicidae). Sociobiology, 37, 491-509.

Beugnon, G., Chagné, P. \& Dejean, A. (2001). Colony structure and foraging behavior in the tropical formicine ant Gigantiops destructor. Insectes Sociaux, 48, 347-351.

Beugnon, G. \& Dejean, A. (1992) Adaptive properties of the chemical trail system of the African weaver ant. Insectes Sociaux, 39, 341-346.

Blüthgen, N. \& Stork, N.E. (2007) Ant mosaics in a tropical rainforest in Australia and elsewhere: a critical review. Austral Ecology, 32, 93-104.

Blüthgen, N., Stork, N.E. \& Fiedler, K. (2004) Bottom-up control and co-occurrence in complex communities: honeydew and nectar determine a rainforest ant mosaic. Oikos, 106, 344-358.

Bolton, B. (2018) Species: Cephalotes atratus (Linnaeus, 1758). Antweb https://www.antweb.org/description.do?rank=species\&name=atratus\&genus=cephalotes. 
414 Camargo, R.X. \& Oliveira, P.S. (2012) Natural history of the Neotropical arboreal ant, Odontomachus

415 hastatus: nest sites, foraging schedule, and diet. Journal of Insect Science, 10, 158.

416 Camarota, F., Powell, S., Melo, A.S., Priest, G., Marquis, R.J. \& Vasconcelos, H.L. (2016) Co-

417 occurrence patterns in a diverse arboreal ant community are explained more by competition than

418 habitat requirements. Ecology and Evolution, 6, 8907-8918.

419 Colwell, R.K. (2013) EstimateS: statistical estimation of species richness and shared species from 420 samples. Version 9. User's Guide: http://purl.oclc.org/estimates.

421 Colwell, R.K., Mao, C.X. \& Chang, J. (2004) Interpolating, extrapolating, and comparing incidence422 based species accumulation curves. Ecology, 85, 2717-2727.

423 Corbara, B., Servigne, P., Dejean, A., Carpenter, J.M. \& Orivel, J. (2018) A mimetic nesting 424 association between a timid social wasp and an aggressive arboreal ant. Comptes Rendus Biologies, $425 \quad 341,182-188$.

426 da Conceição, E.S., Delabie, J.H.C., Castro Della Lucia, T.M., de Oliveira Costa-Neton, A. \& Majer, 427 J.D. (2014) Structural changes in arboreal ant assemblages (Hymenoptera: Formicidae) in an age 428 sequence of cocoa plantations in the south-east of Bahia, Brazil. Austral Entomology, 54, 315-324. 429 Davidson, D.W. (1998) Resource discovery versus resource domination in ants: a functional 430 mechanism for breaking the trade-off. Ecological Entomology, 23, 484-490.

431 Davidson, D.W., Cook, S.C., Snelling, R.R. \& Chua, T.H. (2003) Explaining the abundance of ants in 432 lowland tropical rainforest canopies. Science, 300, 969-972.

433 Davidson, D.W., Lessard, J.-P., Bernau, C.R. \& Cook, S.C. (2007) Tropical ant mosaic in a primary $434 \quad$ Bornean Rain Forest. Biotropica, 39, 468-475.

435 De la Mora, A., Livingston, G. \& Philpott, S.M. (2008) Arboreal ant abundance and leaf miner 436 damage in coffee agroecosystems in Mexico. Biotropica, 40, 742-746.

437 Dejean, A., Azémar, F., Céréghino, R., Leponce, M., Corbara, B., Orivel, J. \& Compin, A. (2016) The 438 dynamics of ant mosaics in tropical rainforests characterized using the Self-Organizing Map 439 algorithm. Insect Science, 23, 630-637.

440 Dejean, A., Corbara, B., Orivel, J. \& Leponce, M. (2007) Rainforest canopy ants: the implications of 441 territoriality and predatory behavior. Functional Ecosystems and Communities, 1, 105-120. 
442 Dejean, A., Corbara, B., Orivel, J., Snelling, R.R., Delabie, J.H.C. \& Belin-Depoux, M. (2000) The 443 importance of ant gardens in the pioneer vegetal formations of French Guiana. Sociobiology, 35, $444 \quad 425-439$.

445 Dejean, A., Delabie, J.H.C., Corbara, B., Azémar, F., Groc, S., Orivel, J. \& Leponce, M. (2012) The 446 ecology and feeding habits of the arboreal trap-jawed ant Daceton armigerum. PLoS ONE, 7 , $447 \quad$ e37683.

448 Dejean, A., Fisher, B.L., Corbara, B., Rarevohitra, R., Randrianaivo, R., Rajemison, B. \& Leponce, M. 449 (2010) Spatial distribution of dominant arboreal ants in a Malagasy coastal rainforest: gaps and $450 \quad$ presence of an invasive species. PLoS ONE, 5, e9319.

451 Dejean, A., Orivel, J., Leponce, M., Compin, A., Delabie, J.H.C., Azémar, F. \& Corbara, B. (2018) 452 Ant-plant relationships in the canopy of an Amazonian rainforest: the presence of an ant mosaic. 453 Biological Journal of the Linnean Society, 125, 344-354.

454 Dejean, A., Ryder, S., Bolton, B., Compin, A., Leponce, M., Azémar, F., Céréghino, R., Orivel, J. \& 455 Corbara, B. (2015) How territoriality and host-tree taxa determine the structure of ant mosaics. The $456 \quad$ Science of Nature, 102, 33.

457 Delabie, J.H.C. (1990) The ant problems of cocoa farms in Brazil. Applied Myrmecology: A World 458 Perspective (ed. by R.K. Vander Meer, K. Jaffe \& A. Cedeño), pp. 555-569, Westview Press, 459 Boulder, Colorado, USA.

460 Delabie, J.H.C., Benton, F.P. \& de Medeiros, M.A. (1991) La polydomie chez les Formicidae 461 arboricoles dans les cacaoyières du Brésil: optimisation de l'occupation de l'espace ou stratégie 462 défensive? Actes des Colloques Insectes Sociaux, 7, 173-178.

463 Djiéto-Lordon, C. \& Dejean, A. (1999a) Innate attraction supplants experience during host plant 464 selection in an obligate plant-ant. Behavioural Processes, 46, 181-187.

Djiéto-Lordon, C. \& Dejean, A. (1999b) Tropical arboreal ant mosaic: innate attraction and imprinting determine nesting site selection in dominant ants. Behavioral Ecology and Sociobiology, 45, 219225.

Dyer, L.A. (2002) A quantification of predation rates, indirect positive effects on plants, and foraging variation of the giant tropical ant, Paraponera clavata. Journal of Insect Science, 2, 18. 
470

471

472

473

474

475

476

477

478

479

480

481

482

483

484

485

486

487

488

489

490

491

492

493

494

495

496

497

Elahi, R. (2005) The effect of water on the ground nesting habits of the giant tropical ant, Paraponera clavata. Journal of Insect Science, $\mathbf{5}, 34$.

Fayle, T.M., Eggleton, P., Manica, A., Yusah, K.M. \& Foster, W.A. (2015) Experimentally testing and assessing the predictive power of species assembly rules for tropical canopy ants. Ecology Letters. 18, 254-262.

Fayle, T.M., Turner, E.C. \& Foster, W.A. (2013) Ant mosaics occur in SE Asian oil palm plantation but not rain forest and are influenced by the presence of nest-sites and non-native species. Ecography, 36, 1051-1057.

Floren, A., Biun, A. \& Linsenmair, K.E. (2002) Arboreal ants as key predators in tropical lowland rainforest trees. Oecologia, 131, 137-44.

Floren, A. \& Linsenmair, K.E. (2000) Do ant mosaics exist in pristine lowland rain forests? Oecologia, 123, 129-137.

Gibernau, M., Orivel, J., Delabie, J.H.C., Barabé, D. \& Dejean, A. An asymmetrical relationship between an arboreal ponerine ant and a trash-basket epiphyte (Araceae). Biological Journal of the Linnean Society, 91, 341-346.

Gotelli, N.J. (2000) Null model analysis of species co-occurrence patterns. Ecology, 81, 2606-2621.

Gotelli, N.J. \& Entsminger, G.L. (2004) EcoSim: Null models software for ecology. Version 7. Acquired Intelligence Inc. \& Kesey-Bear, http://garyentsminger.com/ecosim/index.htm.

Grimaldi, M. \& Riera, B. (2001) Geography and climate. Nouragues. Dynamics and plant-animal interactions in a Neotropical Rainforest (ed. by F. Bongers, P. Charles-Dominique, P.M. Forget, \& M. Théry), pp. 9-18, Kluwer Academic publishers, Dordrecht, The Netherlands.

Groc, S., Delabie, J.H.C., Fernández, F., Leponce, M., Orivel, J., Silvestre, R., Vasconcelos, H.L. \& Dejean, A. (2014) Leaf-litter ant communities in a pristine Guianese rainforest: stable functional structure versus high species turnover. Myrmecological News, 19, 43-51.

Hölldobler, B. \& Wilson, E.O. (1994) Journey to the ants: a story of scientific exploration. Harvard University Press, Cambridge, MA, USA.

Hora, R.R., Vilela, E.F., Fénéron, R., Pezon, A., Fresneau, D. \& Delabie, J.H.C. 2005. Facultative polygyny in Ectatomma tuberculatum (Formicidae, Ectatomminae). Insectes Sociaux, 52, 194-200. 
498 Kenne, M., Djiéto-Lordon, C., Orivel, J., Mony, R., Fabre, A. \& Dejean, A. (2003) Influence of 499 insecticide treatments on ant-hemiptera associations in tropical plantations. Journal of Economic $500 \quad$ Entomology, 96, 251-258.

501 Klimes, P., Fibich, P., Idigel, C., Rimandai, M. (2015) Disentangling the diversity of arboreal ant 502 communities in tropical forest trees. PLOS ONE, 10, e0117853.

503 Klimes, P. (2017) Diversity and specificity of ant-plant interactions in canopy communities: insights 504 from primary and secondary tropical forests in New Guinea. Ant-plant interactions: impacts of 505 humans on terrestrial ecosystems (ed. by P.S. Oliveira \& S. Koptur), pp. 26-51, Cambridge $506 \quad$ University Press, Cambridge, UK.

507 Leponce M., Delabie J.H.C., Jacquemin J., Martin M.C. \& Dejean A. (2019) Tree-dwelling ant survey 508 (Hymenoptera, Formicidae) in Mitaraka, French Guiana. Zoosystema, (in press).

509 Lewis, S.L., Sonke, B., Sunderland, T., Begne, S.K., Lopez-Gonzalez, G., vander Heijden, G.M.F., 510 Phillips, O.L., Affum-Baffoe, K. \& Baker, T.R. (2013) Above-ground biomass and structure of 260 511 African tropical forests. Philosophical Transactions of the Royal Society B: Biological Sciences, $512 \quad 368,20120295$.

513 Longino, J.T. (2003) The Crematogaster (Hymenoptera, Formicidae, Myrmicinae) of Costa Rica. $514 \quad$ Zootaxa, 151, 1-150.

515 Longino, J.T. (2007) A taxonomic review of the genus Azteca in Costa Rica and a global revision of 516 the aurita group. Zootaxa, 1491, 1-63.

517 MacKay, W.P. (1993) A review of the New World ants of the genus Dolichoderus (Hymenoptera: 518 Formicidae). Sociobiology, 22, 1-150.

519 Majer, J.D. (1972) The ant mosaic in Ghana cocoa farms. Bulletin of Entomological Research, 62 , $520 \quad 151-160$.

521 Majer, J.D. (1993) Comparison of the arboreal ant mosaic in Ghana, Brazil, Papua New Guinea and 522 Australia: its structure and influence of ant diversity. Hymenoptera and Biodiversity (ed. by J. 523 LaSalle \& L.D. Gauld), pp. 115-141, CAB International, Wallingford, UK.

524 Majer, J.D., Delabie, J.H.C, Smith, M.R.B. (1994) Arboreal ant community patterns in Brazilian cocoa 525 farms. Biotropica, 26, 73-83. 
Offenberg, J. (2007) The distribution of weaver ant pheromones on host trees. Insectes Sociaux, 54, $248-250$.

Orivel, J. \& Dejean, A. (2001) Ant activity rhythm in a pioneer vegetal formation of French Guiana. Sociobiology, 39, 65-76.

Pfeiffer, M., Tuck, H.C. \& Lay, T.C. (2008) Exploring arboreal ant community composition and cooccurrence patterns in plantations of oil palm (Elaeis guineensis) in Borneo and Peninsular Malaysia. Ecography, 31, 21-32.

Pike, N. (2011) Using false discovery rates for multiple comparisons in ecology and evolution, Methods in Ecology and Evolution, 2, 278-282.

Poncy, O., Sabatier, D., Prévost, M.-F. \& Hardy, I. (2001) The lowland high rainforest. Structure and tree species diversity. Nouragues. Dynamics and plant-animal interactions in a Neotropical Rainforest (ed. by F. Bongers, P. Charles-Dominique, P.M. Forget \& M. Thery), pp. 31-46, Kluwer Academic publishers, Dordrecht, The Netherlands.

R Development Core Team (2015) R: a language and environment for statistical computing. $\mathrm{R}$ Foundation for Statistical Computing, Vienna.

Ribeiro, S.P., Espirito Santo, N.B., Delabie, J.H.C. \& Majer, J.D. (2013) Competition, resources and the ant (Hymenoptera: Formicidae) mosaic: a comparison of upper and lower canopy. Myrmecological News, 18, 99-102.

Schmidt, M. \& Dejean, A. (2018) A dolichoderine ant that constructs traps to collectively ambush prey: convergent evolution with a myrmicine genus. Biological Journal of the Linnean Society, $124,41-46$.

Schnitzer, S., Mascaro, J., \& Carson, W. (2008) Treefall gaps and the maintenance of plant species diversity in tropical forests. Tropical forest community ecology (ed. by W. Carson \& S. Schnitzer), pp. 196-209, Wiley-Blackwell Pub., Chichester, UK.

Souza, A.F. \& Martins, F.R. (2005) Spatial variation and dynamics of flooding, canopy openness, and structure in a Neotropical swamp forest. Plant Ecology, 180, 161-173.

Stefan, A., Schnitzer, S.A. \& Carson W.P. (2010) Lianas suppress tree regeneration and diversity in treefall gaps. Ecology Letters, 13, 849-857. 
554 Styrsky, J.D. \& Eubanks, M.D. (2007) Ecological consequences of interactions between ants and 555 honeydew-producing insects. Proceedings of the Royal Society of London, B Biological Sciences, $556 \quad 274,151-164$.

557 Tobin, J.E. (1997) Competition and coexistence of ants in a small patch of rainforest canopy in 558 Peruvian Amazonia. Journal of the New York Entomological Society, 105, 105-112.

559 Tymen, B., Réjou-Méchain, M., Dalling, J.W., Fauset, S., Feldpausch, T.R., Norden, N., Phillips,

560 O.L., Turner, B.L., Viers, J. \& Chave, J. (2016) Evidence for arrested succession in a liana-infested 561 Amazonian forest. Journal of Ecology, 104, 149-159.

562 van der Meer, R.J. \& Bongers, F. (1996) Formation and closure of canopy gaps in the rain forest at 563 Nouragues, French Guiana. Vegetatio, 126, 167-179.

564 Vicente, R.E. \& Izzo, T.J. (2017) Defining habitat use by the parabiotic ants Camponotus femoratus 565 (Fabricius, 1804) and Crematogaster levior Longino, 2003. Sociobiology, 64, 373-380.

566 Watt, A.D., Stork, N.E. \& Bolton, B. (2002) The diversity and abundance of ants in relation to forest 567 disturbance and plantation establishment in southern Cameroon. Journal of Applied Ecology, 39, $568 \quad 985-998$.

569 Yusah, K.M., Foster, W.A., Reynolds, G. \& Fayle, T.M. (2018) Ant mosaics in Bornean primary rain 570 forest high canopy depend on spatial scale, time of day, and sampling method. Peer $J, 6$, e4231. 
Figure legends

573

574

575

576

577

578

579

580

581

582

583

584

585

586

587

588

589

590

591

592

593

594

595

596

597

598

599

Fig. 1. (a) A large carton nest of Azteca chartifex. (b) A conspicuous ant garden resulting from the association between Camponotus femoratus and Crematogaster levior. The scale bar represents $50 \mathrm{~cm}$.

Fig. 2. Overhead view of the distribution of the trees and their associated territorially dominant ant species in the area studied in the Nouragues Ecological Field Station, French Guiana. The codes correspond to the trees listed in Appendix S1 (see also examples of the projection of African tree crowns for comparison). Note the co-occurrence of two mutually exclusive TDDAs in seven tree crowns (i.e., trees \#11L403; \#11L408; \#11L411; \#11L522; \#11M111; \#11M126; \#11M128), and codominance in 29 trees.

Fig. 3. (a) Individual-based rarefaction (Mao-Tau with $95 \%$ CI, solid lines) illustrating the incompleteness of the survey concerning the tree species ( $\mathrm{N}=141$ identified trees), confirmed by the stability of the singletons (species observed with only one individual, triangles) and doubletons (species with only two individuals, circles). The estimated asymptotic richness of the assemblage obtained by Chao1 is shown as diamonds (Chao1 mean = 175 species; CI95\%: 119-298 tree species). Trees that could not be identified to the species level were excluded from this analysis. (b) Samplebased rarefaction (Mao-Tau with $95 \%$ CI, solid lines) illustrating the near-completeness of the survey concerning the ant species, confirmed by the decrease in uniques (species collected only once, triangles) and duplicates (species collected twice, circles). The estimated asymptotic richness of the assemblage obtained by Chao 2 is shown as diamonds ( $\mathrm{N}=157$ supporting trees).

Fig. 4. Non-metric multidimensional scaling (NMDS) ordination plot showing the ant species (black crosses) according to their host tree taxa (red dots) (Bray-Curtis distance). The 'complete' clustering of ant species in the ordination space according to host tree sample composition delimits eight clusters. The analysis was conducted on the 10 most frequent dominant ants and 31 tree families or subfamilies for the Fabaceae (this corresponds to 144 tree crowns out of the 157 sampled). 
Table 1. List of dominant ant species collected from 157 trees in the Nouragues Ecological Research Station (the total of the percentages is greater than $100 \%$ because one tree crown can shelter several dominant ant species due to cases of co-dominance).

\begin{tabular}{|c|c|c|c|c|}
\hline Ant species & Occurrences & $\begin{array}{l}\text { Frequency } \\
\text { on trees }\end{array}$ & Nesting habits & \\
\hline $\begin{array}{l}\text { Crematogaster } \\
\text { levior }\end{array}$ & 69 & $43.95 \%$ & \multirow{2}{*}{$\begin{array}{l}\text { Carton nests, ant gardens, polydomous, } \\
\text { parabiosis with Camponotus femoratus. } \\
\text { Semi-spherical carton nests, ant gardens, } \\
\text { polydomous, parabiosis with Crematogaster } \\
\text { levior. }\end{array}$} & $\begin{array}{l}\text { Dejean et al. (2000); } \\
\text { Vicente \& Izzo (2017) }\end{array}$ \\
\hline $\begin{array}{l}\text { Camponotus } \\
\text { femoratus }\end{array}$ & 61 & $38.85 \%$ & & $\begin{array}{l}\text { Dejean et al. (2000); } \\
\text { Vicente \& Izzo (2017) }\end{array}$ \\
\hline $\begin{array}{l}\text { Crematogaster } \\
\text { stollii }\end{array}$ & 28 & $17.83 \%$ & $\begin{array}{l}\text { Carton nests in cavities; galleries on tree } \\
\text { trunks and branches; continue underground, } \\
\text { interconnecting trees. }\end{array}$ & Longino (2003) \\
\hline Azteca instabilis & 22 & $14.01 \%$ & $\begin{array}{l}\text { Hemispherical carton nests against tree } \\
\text { trunks or base of main branches, } \\
\text { polydomous. }\end{array}$ & De la Mora et al. (2008) \\
\hline $\begin{array}{l}\text { Ectatomma } \\
\text { tuberculatum }\end{array}$ & 19 & $12.10 \%$ & $\begin{array}{l}\text { Ground-nesting at the base of trees, } \\
\text { polydomous; galleries underground } \\
\text { interconnecting trees. }\end{array}$ & $\begin{array}{l}\text { Delabie (1990); } \\
\text { Hora et al. (2005) }\end{array}$ \\
\hline Azteca jelskii & 16 & $10.19 \%$ & Carton nests in cavities, polydomous. & Longino (2007) \\
\hline $\begin{array}{l}\text { Dolichoderus } \\
\text { bidens }\end{array}$ & 6 & $3.82 \%$ & $\begin{array}{l}\text { Numerous small carton nests under the } \\
\text { leaves, polydomous. }\end{array}$ & $\begin{array}{l}\text { MacKay (1993); } \\
\text { Delabie et al. (1991) } \\
\text { Corbara et al. (2018) }\end{array}$ \\
\hline $\begin{array}{l}\text { Dolichoderus } \\
\text { bispinosus }\end{array}$ & 6 & $3.82 \%$ & Nests in cavities, polydomous. & MacKay (1993) \\
\hline Daceton armigerum & 4 & $2.55 \%$ & $\begin{array}{l}\text { Cavities in old branches of trees, } \\
\text { polydomous. }\end{array}$ & Dejean et al. (2012) \\
\hline Azteca ovaticeps & 4 & $2.55 \%$ & $\begin{array}{l}\text { Nests in hollow trunks and branches of } \\
\text { Cecropia spp. trees. }\end{array}$ & Longino, 2007 \\
\hline $\begin{array}{l}\text { Odontomachus } \\
\text { hastatus }\end{array}$ & 4 & $2.55 \%$ & $\begin{array}{l}\text { Nests in trash baskets formed by palm trees } \\
\text { or Philodendron. }\end{array}$ & $\begin{array}{l}\text { Gibernau et al. (2007); } \\
\text { Camargo \& Oliveira (2012) }\end{array}$ \\
\hline Paraponera clavata & 4 & $2.55 \%$ & Ground-nesting at the base of trees. & Elahi (2015) \\
\hline Azteca chartifex & 3 & $1.91 \%$ & Large, triangular carton nests, polydomous. & $\begin{array}{l}\text { Delabie et al. (1991); } \\
\text { Longino (2007) }\end{array}$ \\
\hline Cephalotes atratus & 2 & $1.27 \%$ & $\begin{array}{l}\text { Large cavities in old branches of trees, } \\
\text { polydomous. }\end{array}$ & Bolton (2018) \\
\hline Azteca brevis & 1 & $0.63 \%$ & $\begin{array}{l}\text { Carton nests in cavities; galleries on tree } \\
\text { trunks and branches; continue underground, } \\
\text { interconnecting trees }\end{array}$ & $\begin{array}{l}\text { Longino, 2007; } \\
\text { Schmidt \& Dejean, 2018) }\end{array}$ \\
\hline Camponotus rapax & 1 & $0.63 \%$ & $\begin{array}{l}\text { Small colonies nesting in cavities in old } \\
\text { branches of trees. }\end{array}$ & $\begin{array}{l}\text { Gibernau et al. (2007); } \\
\text { AD, BC pers. com }\end{array}$ \\
\hline
\end{tabular}


Table 2. Associations between the most frequent species (frequency on the 157 trees sampled $>10 \%$ ) by decreasing rank of occurrence and tested using Chi-square tests ( 1 d.f., Yates' correction). Symbols indicate the nature of the association: "+" positive, "-" negative, "0" not significant.

\begin{tabular}{|c|c|c|c|c|c|c|c|}
\hline & & Frequency & 1 & 2 & 3 & 4 & 5 \\
\hline 1 & Crematogaster levior & $44 \%$ & & & & & \\
\hline 2 & Camponotus femoratus & $39 \%$ & + & & & & \\
\hline 3 & Crematogaster stolli & $18 \%$ & - & - & & & \\
\hline 4 & Azteca instabilis & $14 \%$ & - & - & 0 & & \\
\hline 5 & Ectatomma tuberculatum & $12 \%$ & - & - & + & 0 & \\
\hline 6 & Azteca jelskii & $10 \%$ & - & - & 0 & 0 & 0 \\
\hline
\end{tabular}


Table 3. Comparison of the parabiotic, ant-garden ants Camponotus femoratus and Crematogaster levior and all other territorially dominant arboreal ant species (TDAAs) between five Guianese rainforests. Statistical comparison: Fisher's exact-tests and false discovery rate (FDR; BH correction) adjustment for simultaneous comparisons.

\begin{tabular}{|c|c|c|c|c|c|}
\hline & $\begin{array}{c}\text { A- } \\
\text { Nouragues } \\
\text { (plateau) }\end{array}$ & $\begin{array}{c}\text { B- } \\
\text { Paracou }\end{array}$ & $\begin{array}{c}\text { C- } \\
\text { Mitaraka } \\
\text { (plateau) }\end{array}$ & $\begin{array}{c}\text { D- } \\
\text { Mitaraka } \\
\text { (swamp) }\end{array}$ & $\begin{array}{c}\text { E- } \\
\text { Petit Saut }\end{array}$ \\
\hline Ant-garden ants & $69(45.7 \%)$ & $27(20.15 \%)$ & $6(20 \%)$ & $15(50 \%)$ & $0(0 \%)$ \\
\hline All other TDAAs & $82(54.3 \%)$ & $107(79.85 \%)$ & $24(80 \%)$ & $15(50 \%)$ & $45(100 \%)$ \\
\hline \multirow[t]{2}{*}{ Total } & 151 & 134 & 30 & 30 & 45 \\
\hline & $A \times B$ & $A x C$ & $A x D$ & AxE & $\mathrm{BxC}$ \\
\hline \multirow[t]{2}{*}{ FDR adjustment } & $\begin{array}{l}P<0.001 \\
P<0.05\end{array}$ & $\begin{array}{c}P=0.0088 \\
P<0.05\end{array}$ & $\begin{array}{c}P=0.693 \\
N S\end{array}$ & $\begin{array}{c}P=0.0001 \\
P<0.05\end{array}$ & $\begin{array}{l}P=1 \\
N S\end{array}$ \\
\hline & $\mathrm{BxD}$ & $\mathrm{BxE}$ & CxD & CxE & DxE \\
\hline $\begin{array}{l}\text { Fisher's exact-test } \\
\text { FDR adjustment }\end{array}$ & $\begin{array}{c}P=0.002 \\
P<0.05\end{array}$ & $\begin{array}{l}P=0.001 \\
P<0.05\end{array}$ & $\begin{array}{c}P=0.0292 \\
P<0.05\end{array}$ & $\begin{array}{c}P=0.0029 \\
P<0.05\end{array}$ & $\begin{array}{c}P<0.0001 \\
P<0.05\end{array}$ \\
\hline
\end{tabular}



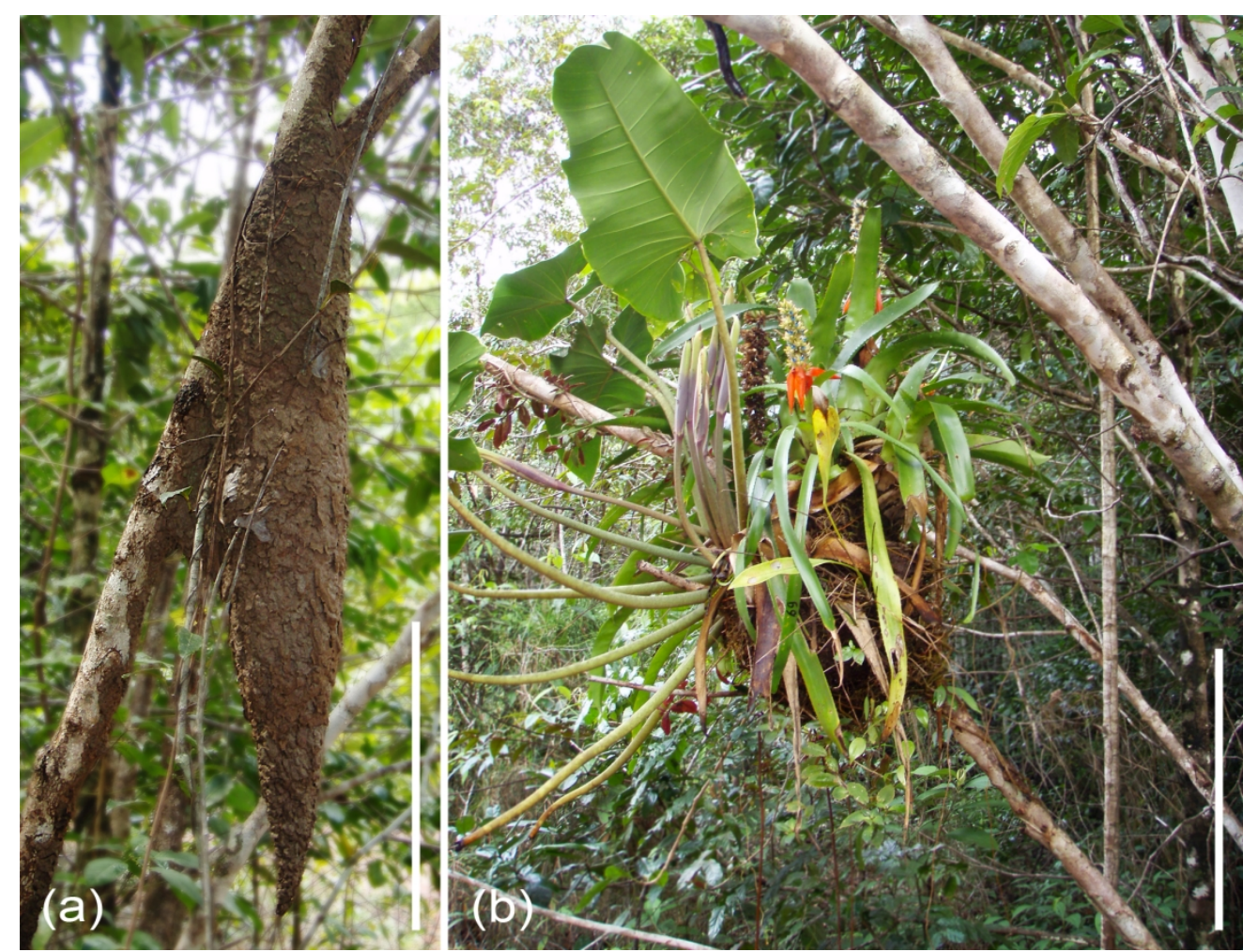

Fig. 1. (a) A large carton nest of Azteca chartifex. (b) A conspicuous ant garden resulting from the association between Camponotus femoratus and Crematogaster levior. The scale bar represents $50 \mathrm{~cm}$. 


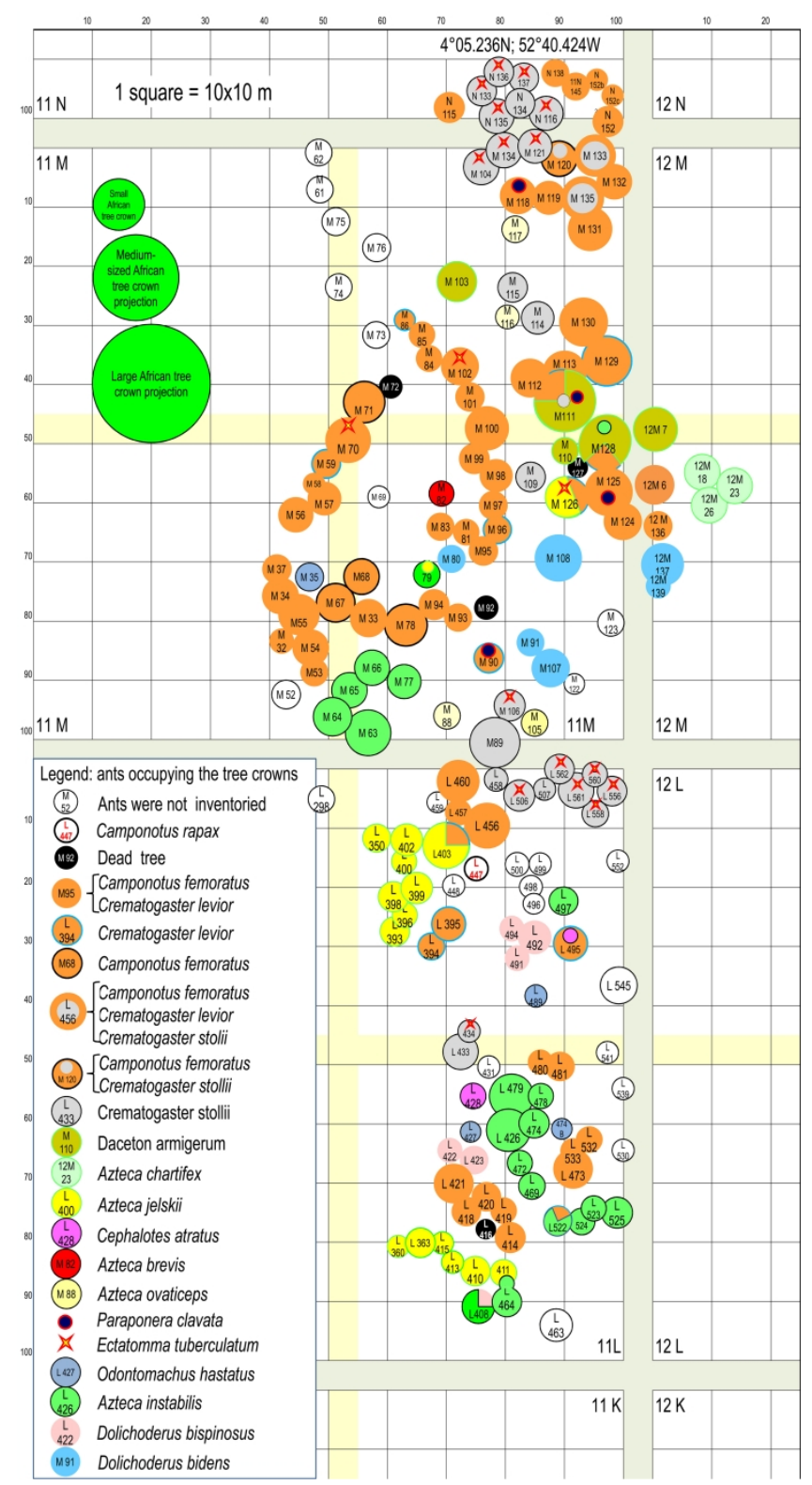

Fig. 2. Overhead view of the distribution of the trees and their associated territorially dominant ant species in the area studied in the Nouragues Ecological Field Station, French Guiana. The codes correspond to the trees listed in Appendix S1 (see also examples of the projection of African tree crowns for comparison). 

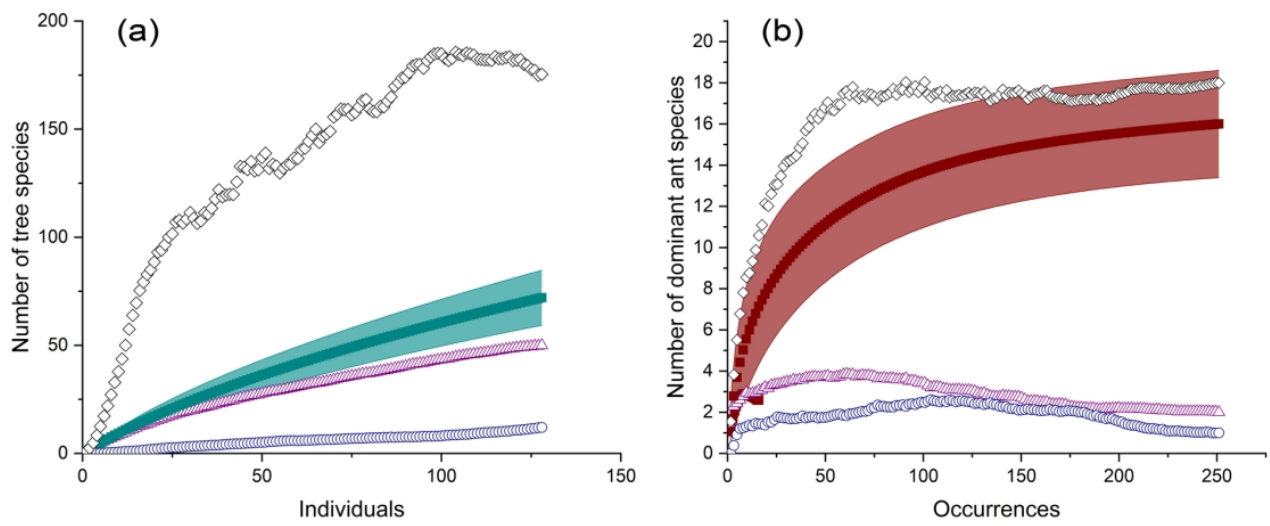

Fig. 3. (a) Individual-based rarefaction (Mao-Tau with $95 \% \mathrm{CI}$, solid lines) illustrating the incompleteness of the survey concerning the tree species ( $N=141$ identified trees), confirmed by the stability of the singletons (species observed with only one individual, triangles) and doubletons (species with only two individuals, circles). The estimated asymptotic richness of the assemblage obtained by Chao 1 is shown as diamonds (Chao1 mean $=175$ species; CI95\%: 119-298 tree species). Trees that could not be identified to the species level were excluded from this analysis. (b) Sample-based rarefaction (Mao-Tau with $95 \%$ CI, solid lines) illustrating the near-completeness of the survey concerning the ant species, confirmed by the decrease in uniques (species collected only once, triangles) and duplicates (species collected twice, circles). The estimated asymptotic richness of the assemblage obtained by Chao2 is shown as diamonds ( $\mathrm{N}=157$ supporting trees).

$165 \times 67 \mathrm{~mm}(300 \times 300 \mathrm{DPI})$ 


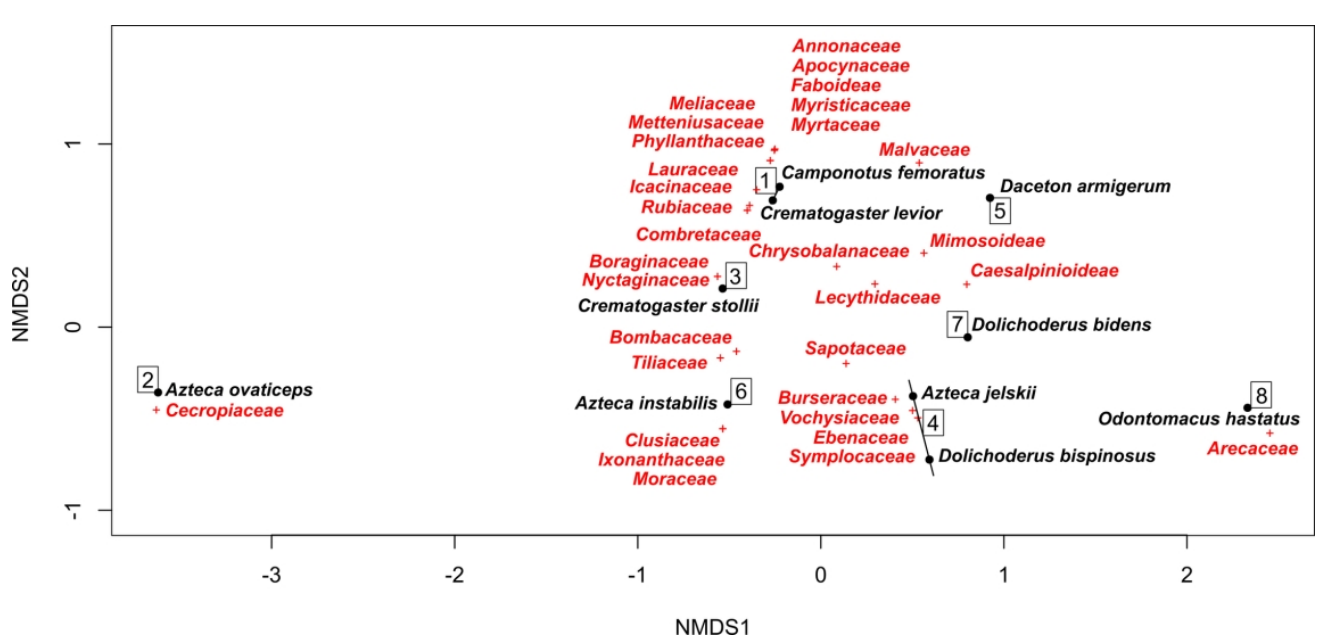

Fig. 4. Non-metric multidimensional scaling (NMDS) ordination plot showing the ant species (black crosses) according to their host tree taxa (red dots) (Bray-Curtis distance). The 'complete' clustering of ant species in the ordination space according to host tree sample composition delimits eight clusters. The analysis was conducted on the 10 most frequent dominant ants and 31 tree families or subfamilies for the Fabaceae (this corresponds to 144 tree crowns out of the 157 sampled).

$189 \times 88 \mathrm{~mm}(300 \times 300 \mathrm{DPI})$ 
Appendix S1. A. Identification of the 157 trees studied in the Nouragues Ecological Research Station and the dominant ant species they sheltered in their crowns (the codes are nailed to the trunks of the trees at $\approx 1.60 \mathrm{~m}$ in height). (LD): light-demanding tree species including pioneer tree species (26 species out of 120 taxa identified).

\begin{tabular}{|c|c|c|c|}
\hline Tree family & Tree species & CODE & Territorially dominant arboreal species \\
\hline Vochysiaceae & Qualea rosea & $11 \mathrm{~L} 350$ & Azteca jelskii \\
\hline Lecythidaceae & Lecythis persistens & $11 \mathrm{~L} 360$ & Azteca jelskii \\
\hline Burseraceae & Protium sagotianum & $11 \mathrm{~L} 363$ & Azteca jelskii \\
\hline Lecythidaceae & Lecythis poiteaui & $11 L 393$ & Azteca jelskii \\
\hline Cardiopteridaceae & Dendrobangia boliviana & $11 \mathrm{~L} 394$ & Crematogaster levior \\
\hline Caesalpinioideae & Vouacapoua americana & $11 \mathrm{~L} 395$ & Crematogaster levior \\
\hline Lecythidaceae & Lecythis poiteaui & $11 \mathrm{~L} 396$ & Azteca jelskii \\
\hline Burseraceae & Protium sagotianum & $11 \mathrm{~L} 398$ & Azteca jelskii \\
\hline Sapotaceae & Pouteria gonggrijpii & $11 L 399$ & Azteca jelskii \\
\hline Chrysobalanaceae & Licania canescens & $11 \mathrm{~L} 400$ & Azteca jelskii \\
\hline Symplocaceae & Symplocos martinicensis & $11 \mathrm{~L} 402$ & Azteca jelskii \\
\hline Lecythidaceae & Lecythis idatimon & 11L403 & Azteca jelskii, Crematogaster levior \\
\hline Caesalpinioideae & Vouacapoua americana & $11 \mathrm{~L} 408$ & Azteca instabilis, Dolichoderus bispinosus \\
\hline Ebenaceae & Diospyros capreifolia & $11 L 410$ & Azteca jelskii \\
\hline Lecythidaceae & Eschweilera coriacea & $11\llcorner 411$ & Azteca instabilis, Azteca jelskii \\
\hline Caesalpinioideae & Vouacapoua americana & $11 \mathrm{~L} 413$ & Azteca jelskii \\
\hline Annonaceae & Fusaea longifolia & $11 \mathrm{~L} 414$ & Camponotus femoratus, Crematogaster levior \\
\hline Lecythidaceae & Eschweilera coriacea & $11 \mathrm{~L} 415$ & Azteca jelskii \\
\hline Burseraceae & Tetragastris altissima & $11 L 418$ & Camponotus femoratus, Crematogaster levior \\
\hline Combretaceae & Buchenavia sp. & $11 L 419$ & Camponotus femoratus, Crematogaster levior \\
\hline Burseraceae & Protium morii & $11 \mathrm{~L} 420$ & Camponotus femoratus, Crematogaster levior \\
\hline Caesalpinioideae & Vouacapoua americana & 11L421 & Camponotus femoratus, Crematogaster levior \\
\hline Sapotaceae & Pouteria decorticans & $11 \mathrm{~L} 422$ & Dolichoderus bispinosus \\
\hline Burseraceae & Unidentified & $11 \mathrm{~L} 423$ & Dolichoderus bispinosus \\
\hline Ixonanthaceae & Cyrillopsis paraensis & $11 \mathrm{~L} 426$ & Azteca instabilis \\
\hline Arecaceae & Astrocaryum sciophilum & $11 \mathrm{~L} 427$ & Odontomachus hastatus \\
\hline Burseraceae & Protium opacum & $11 \mathrm{~L} 428$ & Cephalotes atratus \\
\hline Lecythidaceae & Lecythis persistens & $11 \mathrm{~L} 433$ & Crematogaster stollii \\
\hline Nyctaginaceae & Neea floribunda & $11 \mathrm{~L} 434$ & Crematogaster stollii, Ectatomma tuberculatum \\
\hline Sapotaceae & Micropholis cayennensis & $11 \mathrm{~L} 447$ & Camponotus rapax \\
\hline Malvaceae & Sterculia pruriens (LD) & $11 \mathrm{~L} 456$ & Camponotus femoratus, Crematogaster levior \\
\hline Lauraceae & Ocotea percurrens & $11 \mathrm{~L} 457$ & Camponotus femoratus, Crematogaster levior \\
\hline Combretaceae & Buchenavia sp. & $11 L 458$ & Crematogaster stollii \\
\hline Sapotaceae & Pradosia ptychandra & $11 \mathrm{~L} 460$ & Camponotus femoratus, Crematogaster levior \\
\hline Lecythidaceae & Couratari oblongifolia & $11 \mathrm{~L} 464$ & Azteca instabilis \\
\hline Cecropiaceae & Pourouma tomentosa (LD) & $11 \mathrm{~L} 469$ & Azteca instabilis \\
\hline Vochysiaceae & Qualea rosea & 11L472 & Azteca instabilis \\
\hline Meliaceae & Carapa procera & $11 \mathrm{~L} 473$ & Camponotus femoratus, Crematogaster levior \\
\hline Mimosoideae & Inga gracilifolia (LD) & $11\llcorner 474$ & Azteca instabilis \\
\hline Arecaceae & Astrocaryum sciophilum & 11L474 B & Odontomachus hastatus \\
\hline
\end{tabular}




\begin{tabular}{|c|c|c|c|}
\hline Clusiaceae & Symphonia globulifera & $11 \mathrm{~L} 478$ & Azteca instabilis \\
\hline Caesalpinioideae & Vouacapoua americana & $11 \mathrm{~L} 479$ & Azteca instabilis \\
\hline Lecythidaceae & Eschweilera grandiflora & $11 \mathrm{~L} 480$ & Camponotus femoratus, Crematogaster levior \\
\hline Lecythidaceae & Lecythis persistens & 11L481 & Camponotus femoratus, Crematogaster levior \\
\hline Arecaceae & Astrocaryum sciophilum & $11 L 489$ & Odontomachus hastatus \\
\hline Vochysiaceae & Erisma floribundum & $11 \mathrm{~L} 491$ & Dolichoderus bispinosus \\
\hline Sapotaceae & Manilkara bidentata & 11L492 & Dolichoderus bispinosus \\
\hline Sapotaceae & Chrysophyllum Iucentifolium & $11 \mathrm{~L} 494$ & Dolichoderus bispinosus \\
\hline Lecythidaceae & Eschweilera coriacea & $11 \mathrm{~L} 495$ & Crematogaster levior, Cephalotes atratus \\
\hline Mimosoideae & Inga huberi (LD) & 11L497 & Azteca instabilis \\
\hline Vochysiaceae & Qualea rosea & $11 \mathrm{~L} 506$ & Crematogaster stollii, Ectatomma tuberculatum \\
\hline Sapotaceae & Pouteria guianensis & $11 \mathrm{~L} 507$ & Crematogaster stollii \\
\hline Bombacaceae & Quararibea duckei & 11L522 & Azteca instabilis, Crematogaster levior \\
\hline Tiliaceae & Apeiba glabra (LD) & 11L523 & Azteca instabilis \\
\hline Lecythidaceae & Couratari multiflora & 11L524 & Azteca instabilis \\
\hline Sapotaceae & Pouteria guianensis & 11L525 & Azteca instabilis \\
\hline Chrysobalanaceae & Licania canescens & 11L532 & Camponotus femoratus, Crematogaster levior \\
\hline Malvaceae & Sterculia sp. (LD) & $11 \mathrm{~L} 533$ & Camponotus femoratus, Crematogaster levior \\
\hline Lecythidaceae & Eschweilera grandiflora & $11 \mathrm{~L} 556$ & Crematogaster stollii, Ectatomma tuberculatum \\
\hline Lecythidaceae & Lecythis persistens & $11 \mathrm{~L} 558$ & Crematogaster stollii, Ectatomma tuberculatum \\
\hline Cardiopteridaceae & Dendrobangia boliviana & $11 \mathrm{~L} 560$ & Crematogaster stollii, Ectatomma tuberculatum \\
\hline Cardiopteridaceae & Dendrobangia boliviana & $11 \mathrm{~L} 561$ & Crematogaster stollii, Ectatomma tuberculatum \\
\hline Lauraceae & Ocotea sp. & 11L562 & Crematogaster stollii, Ectatomma tuberculatum \\
\hline Sapotaceae & Chrysophyllum sp. & $11 \mathrm{M} 32$ & Camponotus femoratus, Crematogaster levior \\
\hline Caesalpinioideae & Vouacapoua americana & $11 \mathrm{M} 33$ & Camponotus femoratus, Crematogaster levior \\
\hline Myristicaceae & Virola kwatae & $11 \mathrm{M} 34$ & Camponotus femoratus, Crematogaster levior \\
\hline Caesalpinioideae & Vouacapoua americana & $11 \mathrm{M} 35$ & Odontomachus hastatus \\
\hline Lecythidaceae & Eschweilera coriacea & $11 \mathrm{M} 37$ & Camponotus femoratus, Crematogaster levior \\
\hline Sapotaceae & Chrysophyllum Iucentifolium & $11 \mathrm{M} 53$ & Camponotus femoratus, Crematogaster levior \\
\hline Sapotaceae & Chrysophyllum Iucentifolium & $11 \mathrm{M} 54$ & Camponotus femoratus, Crematogaster levior \\
\hline Myristicaceae & Virola kwatae & $11 \mathrm{M} 55$ & Camponotus femoratus, Crematogaster levior \\
\hline Lecythidaceae & Eschweilera coriacea & $11 \mathrm{M} 56$ & Camponotus femoratus, Crematogaster levior \\
\hline Sapotaceae & Pouteria oblanceolata & $11 \mathrm{M} 57$ & Camponotus femoratus, Crematogaster levior \\
\hline Meliaceae & Carapa sp. & $11 \mathrm{M} 58$ & Camponotus femoratus, Crematogaster levior \\
\hline Sapotaceae & Micropholis guyanensis & $11 \mathrm{M} 59$ & Crematogaster levior \\
\hline Sapotaceae & Chrysophyllum sp. & $11 \mathrm{M} 63$ & Azteca instabilis \\
\hline Lecythidaceae & sp. & $11 \mathrm{M} 64$ & Azteca instabilis \\
\hline Moraceae & sp. & $11 \mathrm{M} 65$ & Azteca instabilis \\
\hline Lecythidaceae & Lecythis persistens & $11 \mathrm{M} 66$ & Azteca instabilis \\
\hline Sapotaceae & sp. & $11 \mathrm{M} 67$ & Camponotus femoratus \\
\hline Lecythidaceae & Eschweilera coriacea & $11 \mathrm{M} 68$ & Camponotus femoratus \\
\hline Lecythidaceae & Eschweilera coriacea & $11 \mathrm{M} 70$ & Camponotus femoratus, Crematogaster levior, Ectatomma tuberculatum \\
\hline Caesalpinioideae & Vouacapoua americana & $11 \mathrm{M} 71$ & Camponotus femoratus \\
\hline Sapotaceae & Pradosia ptychandra & $11 \mathrm{M} 77$ & Azteca instabilis \\
\hline Myristicaceae & Virola micheliil & $11 \mathrm{M} 78$ & Camponotus femoratus \\
\hline Caesalpinioideae & Vouacapoua americana & $11 \mathrm{M} 79$ & Azteca instabilis, Azteca jelskii \\
\hline
\end{tabular}




\begin{tabular}{|c|c|c|c|}
\hline Caesalpinioideae & Vouacapoua americana & $11 \mathrm{M} 80$ & Dolichoderus bidens \\
\hline Faboideae & Swartzia benthamiana & $11 \mathrm{M} 81$ & Camponotus femoratus, Crematogaster levior \\
\hline Malvaceae & Sterculia sp. (LD) & $11 \mathrm{M} 82$ & Azteca brevis \\
\hline Cardiopteridaceae & Dendrobangia boliviana & $11 \mathrm{M} 83$ & Camponotus femoratus, Crematogaster levior \\
\hline Lecythidaceae & Eschweilera coriacea & $11 \mathrm{M} 84$ & Camponotus femoratus, Crematogaster levior \\
\hline Apocynaceae & Aspidosperma helstonei & $11 \mathrm{M} 85$ & Camponotus femoratus, Crematogaster levior \\
\hline Phyllanthaceae & Hyeronima alchorneoides & $11 \mathrm{M} 86$ & Crematogaster levior \\
\hline Cecropiaceae & Cecropia obtusa (LD) & $11 \mathrm{M} 88$ & Azteca ovaticeps \\
\hline Sapotaceae & Chrysophyllum Iucentifolium & $11 \mathrm{M} 89$ & Crematogaster stollii \\
\hline Lecythidaceae & Lecythis persistens & $11 \mathrm{M} 90$ & Crematogaster levior, Paraponera clavata \\
\hline Vochysiaceae & Qualea rosea & $11 \mathrm{M} 91$ & Dolichoderus bidens \\
\hline Myristicaceae & Iryanthera sp. & $11 \mathrm{M} 93$ & Camponotus femoratus, Crematogaster levior \\
\hline Apocynaceae & Geissospermum sp. & $11 \mathrm{M} 94$ & Camponotus femoratus, Crematogaster levior \\
\hline Chrysobalanaceae & Licania majuscula & $11 \mathrm{M} 95$ & Camponotus femoratus, Crematogaster levior \\
\hline Caesalpinioideae & Sclerolobium melinonii & $11 \mathrm{M} 96$ & Crematogaster levior \\
\hline Myrtaceae & Guettarda acreana & $11 \mathrm{M} 97$ & Camponotus femoratus, Crematogaster levior \\
\hline Not identified & & $11 \mathrm{MM} 98$ & Camponotus femoratus, Crematogaster levior \\
\hline Malvaceae & Sterculia sp. (LD) & & Camponotus femoratus, Crematogaster levior \\
\hline Myrtaceae & Guettarda acreana & $11 \mathrm{M} 100$ & Camponotus femoratus, Crematogaster levior \\
\hline Mimosoideae & Inga alba (LD) & $11 \mathrm{M} 101$ & Camponotus femoratus, Crematogaster levior \\
\hline Myrtaceae & Guettarda acreana & $11 \mathrm{M} 102$ & Camponotus femoratus, Crematogaster levior, Ectatomma tuberculatum \\
\hline Lecythidaceae & Eschweilera grandiflora & $11 \mathrm{M} 103$ & Daceton armigerum \\
\hline Boraginaceae & Cordia sp. & $11 \mathrm{M} 104$ & Crematogaster stollii, Ectatomma tuberculatum \\
\hline Cecropiaceae & Cecropia obtusa (LD) & $11 \mathrm{M} 105$ & Azteca ovaticeps \\
\hline Cecropiaceae & Pourouma sp. (LD) & $11 \mathrm{M} 106$ & Crematogaster stollii, Ectatomma tuberculatum \\
\hline Mimosoideae & Inga melinonis (LD) & $11 \mathrm{M} 107$ & Dolichoderus bidens \\
\hline Lecythidaceae & Eschweilera grandiflora & $11 \mathrm{M} 108$ & Dolichoderus bidens \\
\hline Lecythidaceae & Eschweilera grandiflora & $11 \mathrm{M} 109$ & Crematogaster stollii \\
\hline Malvaceae & Sterculia sp. (LD) & $11 \mathrm{M} 110$ & Daceton armigerum \\
\hline Caesalpinioideae & Pseudopiptadenia suaveolens & $11 \mathrm{M} 111$ & Da. armigerum, Az. instabilis, Cre. levior, Para. clavata, Cre. stollii \\
\hline Sapotaceae & Micropholis guyanensis & $11 \mathrm{M} 112$ & Camponotus femoratus, Crematogaster levior \\
\hline Malvaceae & Sterculia sp. (LD) & $11 \mathrm{M} 113$ & Camponotus femoratus, Crematogaster levior \\
\hline Malvaceae & Sterculia sp. (LD) & $11 \mathrm{M} 114$ & Crematogaster stollii \\
\hline Lecythidaceae & Couratari guianensis & $11 \mathrm{M} 115$ & Crematogaster stollii \\
\hline Cecropiaceae & Cecropia obtusa (LD) & $11 \mathrm{M} 116$ & Azteca ovaticeps \\
\hline Cecropiaceae & Cecropia obtusa (LD) & $11 \mathrm{M} 117$ & Azteca ovaticeps \\
\hline Meliaceae & Carapa sp. & $11 \mathrm{M} 118$ & Camponotus femoratus, Crematogaster levior, Paraponera clavata \\
\hline Lauraceae & sp. & $11 \mathrm{M} 119$ & Camponotus femoratus, Crematogaster levior \\
\hline Caesalpinioideae & Parkia nitida & $11 \mathrm{M} 120$ & Camponotus femoratus, Crematogaster stollii \\
\hline Boraginaceae & Cordia sp. & $11 \mathrm{M} 121$ & Crematogaster stollii, Ectatomma tuberculatum \\
\hline Sapotaceae & Pouteria eugeniifolia & $11 \mathrm{M} 124$ & Camponotus femoratus, Crematogaster levior \\
\hline Apocynaceae & Aspidosperma marcgravianum & $11 \mathrm{M} 125$ & Camponotus femoratus, Crematogaster levior, Paraponera clavata \\
\hline Caesalpinioideae & Vouacapoua americana & $11 \mathrm{M} 126$ & Azteca jelskii, Crematogaster levior, Ectatomma tuberculatum \\
\hline Caesalpinioideae & Vouacapoua americana & $11 \mathrm{M} 128$ & Azteca instabilis, Crematogaster levior, Daceton armigerum \\
\hline Mimosoideae & Inga capitata (LD) & $11 \mathrm{M} 129$ & Crematogaster levior \\
\hline Mimosoideae & Inga flagelliformis (LD) & $11 \mathrm{M} 130$ & Camponotus femoratus, Crematogaster levior \\
\hline
\end{tabular}




\begin{tabular}{llrl} 
Sapotaceae & Chrysophyllum lucentifolium & $11 \mathrm{M} 131$ & Camponotus femoratus, Crematogaster levior \\
Cardiopteridaceae & Dendrobangia boliviana & $11 \mathrm{M} 132$ & Camponotus femoratus, Crematogaster levior \\
Rubiaceae & Guettarda acreana & $11 \mathrm{M} 133$ & Camponotus femoratus, Crematogaster levior, Crematogaster stollii \\
Tiliaceae & Apeiba glabra (LD) & $11 \mathrm{M} 134$ & Crematogaster stollii, Ectatomma tuberculatum \\
Not identified & & $11 \mathrm{M} 135$ & Camponotus femoratus, Crematogaster levior, Crematogaster stollii \\
Not identified & & $11 \mathrm{~N} 115$ & Camponotus femoratus, Crematogaster levior \\
Not identified & & $11 \mathrm{~N} 116$ & Crematogaster stollii, Ectatomma tuberculatum \\
Not identified & & $11 \mathrm{~N} 133$ & Crematogaster stollii, Ectatomma tuberculatum \\
Not identified & & $11 \mathrm{~N} 134$ & Crematogaster stollii \\
Mimosoideae & Inga rubiginosa (LD) & $11 \mathrm{~N} 135$ & Crematogaster stollii, Ectatomma tuberculatum \\
Not identified & & $11 \mathrm{~N} 136$ & Crematogaster stollii, Ectatomma tuberculatum \\
Mimosoideae & Inga leiocalycina (LD) & $11 \mathrm{~N} 137$ & Crematogaster stollii, Ectatomma tuberculatum \\
Not identified & & $11 \mathrm{~N} 138$ & Camponotus femoratus, Crematogaster levior \\
Caesalpinioideae & Vouacapoua americana & $11 \mathrm{~N} 145$ & Camponotus femoratus, Crematogaster levior \\
Not identified & & $11 \mathrm{~N} 152$ & Camponotus femoratus, Crematogaster levior \\
Not identified & & $11 \mathrm{~N} 152 \mathrm{~b}$ & Camponotus femoratus, Crematogaster levior \\
Not identified & & $11 \mathrm{~N} 152 \mathrm{C}$ & Camponotus femoratus, Crematogaster levior \\
Lecythidaceae & Eschweilera coriacea & $12 \mathrm{M} 6$ & Camponotus femoratus, Crematogaster levior \\
Mimosoideae & Inga stipularis (LD) & $12 \mathrm{M} 7$ & Daceton armigerum \\
Metteniusaceae & Poraqueiba guianensis & $12 \mathrm{M} 136$ & Camponotus femoratus, Crematogaster levior \\
Lecythidaceae & Lecythis persistens & $12 \mathrm{M} 137$ & Dolichoderus bidens \\
Mimosoideae & Inga thibaudiana (LD) & $12 \mathrm{M} 139$ & Dolichoderus bidens \\
Lecythidaceae & Eschweilera coriacea & $12 \mathrm{M} 18$ & Azteca chartifex \\
Caesalpinioideae & Vouacapoua americana & $12 \mathrm{M} 23$ & Azteca chartifex (very large nest) \\
Lecythidaceae & Eschweilera coriacea & $12 \mathrm{M} 26$ & Azteca chartifex \\
\hline 157 TRES & &
\end{tabular}

\section{TREES}

26 light-demanding tree species out of 146 trees identified; $17.8 \%$

The myrmecophytic Cecropia obtusa was not considered in the statistics because it is specifically associated with Azteca ovaticeps.

B. For comparison, selection of light-demanding tree species in the forest of Paracou, French Guiana (see Dejean et al., 2018).

\begin{tabular}{llrl}
\hline Tree family & Tree species & CODE & Territorially dominant arboreal species \\
\hline Anacardiaceae & Tapirira sp. & 139 & Crematogaster levior \\
Cecropiaceae & Coussapoa sp. & 151 & Azteca instabilis \\
Celastraceae & Goupia glabra & 85 & Azteca chartifex \\
Celastraceae & Goupia glabra & 15 & Azteca chartifex \\
Celastraceae & Goupia glabra & 159 & Camponotus femoratus \\
Faboideae & Swartzia panacoco & 91 & Azteca instabilis \\
Faboideae & Swartzia panacoco & 92 & Azteca instabilis \\
Faboideae & Swartzia panacoco & 153 & Azteca instabilis \\
Mimosoideae & Inga alba & 40 & Azteca chartifex \\
Mimosoideae & Inga alba & 34 & Azteca instabilis \\
Mimosoideae & Inga huberi & 25 & Azteca jelskii
\end{tabular}




$\begin{array}{llrl}\text { Malvaceae } & \text { Sterculia sp. } & 163 & \text { Camponotus femoratus, Crematogaster levior } \\ \text { Malvaceae } & \text { Sterculia sp. } & 164 & \text { Camponotus femoratus, Crematogaster levior } \\ \text { Malvaceae } & \text { Sterculia sp. } & 168 & \text { Camponotus femoratus, Crematogaster levior } \\ \text { Malvaceae } & \text { Sterculia sp. } & 162 & \text { Neoponera goeldii } \\ \text { Malvaceae } & \text { Sterculia sp. } & 138 & \text { Crematogaster levior } \\ \text { Malvaceae } & \text { Sterculia sp. } & 172 & \text { Azteca jelskii } \\ \text { Malvaceae } & \text { Sterculia sp. } & 178 & \text { Azteca gnava } \\ \text { Moraceae } & \text { Brosimum guianense } & 39 & \text { Dolichoderus quadridenticulatus } \\ \text { Moraceae } & \text { Brosimum rubescens } & 123 & \text { Azteca jelskii } \\ \text { Moraceae } & \text { Heliocostylis pedunculata } & 19 & \text { Azteca instabilis } \\ \text { Moraceae } & \text { Heliocostylis pedunculata } & 80 & \text { Dolichoderus quadridenticulatus }\end{array}$

22 light-demanding trees out of 131 identified; $16.79 \%$; 134 trees monitored in total

The discrimination of light-demanding tree species was based on Newbery et al. (1985), Roggy \& Prévost (1999) and

Gourlet-Fleury et al. (2004); we would like to acknowledge Dr. Jérôme Chave for verifying our list of tree species.

References

Dejean, A., Orivel, J., Leponce, M., Compin, A., Delabie, J.H.C., Azémar, F. \& Corbara, B. (2018) Ant-plant relationships in the canopy of an Amazonian rainforest: the presence of an ant mosaic. Biological Journal of the Linnean Society, 125, 344-354.

Gourlet-Fleury, S., Guehl, J.-M. \& Laroussinie, O. (2004) Ecology and management of a Neotropical Rainforest. Lessons drawn from Paracou, a long-term experimental research site in French Guiana. Elsevier, Paris.

Newbery, D.McC. \& de Foresta, H. (1985) Herbivory and defense in pioneer, gap and understory trees of tropical rain forests in French Guiana. Biotropica, 17, 238-244.

Roggy, J.C. \& Prévost M.-F. (1999) Nitrogen-fixing legumes and sylvigenesis in a rain forest in French Guiana: a taxonomic and ecological approach. New Phytology, 144, 283-294. 